\title{
Assessment of Selected European and Asian Countries COVID-19 Statuses Using Entropy and MAUT Methods
}

DOI: $10.26466 /$ opus. 943167

\author{
Murat Bolelli* \\ * Assoc. Prof. Dr., Istanbul Altınbaş University, Istanbul/Turkey \\ E-Mail: murat.bolelli@gmail.com \\ ORCID: $\underline{0000-0002-9707-1387}$
}

\begin{abstract}
Purpose of this study is to assess selected European and Asian countries COVID-19 statuses by using Entropy and Multi Attribute Utility Theory (MAUT) Multi Criteria Decision Making methods. Data for the research is collected from Our World in Data databases as of April 15th, 2021. In line with the literature, fourteen criteria are selected to make the assessment. Entropy method is used for objectively weighting the criteria that returned following order: population density $(15.6 \%)$, people fully vaccinated per hundred (12.1\%), total tests per thousand $(10.2 \%)$, diabetes prevalence $(8.9 \%)$, positive rate $(8.5 \%)$, cardiovascular death rate ( $8.3 \%)$, total deaths per million (7.3\%), people vaccinated per hundred $(6.1 \%)$, total cases per million (5.2\%), hospital beds per thousand (4.7\%), nurses and midwives per thousand $(4.1 \%)$, stringency index (3.4\%), medical Dr. per thousand (3.1\%) and share of the population that is 65 years and older (2.6\%). After processing countries by using MAUT method with the criteria weights obtained, first five countries are found to be Bahrain, Serbia, Slovakia, Israel and Slovenia, last five countries are Malaysia, Norway, Japan, Finland and South Korea. Implications of the results are discussed and future research areas are suggested.
\end{abstract}

Keywords: COVID-19, Entropy, MAUT, Multi Criteria Decision Making. 


\title{
Seçilmiş Avrupa ve Asya Ülkelerinin COVID-19 Durumlarının Entropi ve MAUT Yöntemleri ile Değerlendirilmesi
}

\begin{abstract}
Öz
Bu çalışmanın amacı araştırmaya konu edilen Avrupa ve Asya ülkelerinin COVID-19 durumlarının entropi ve çok nitelikli fayda teorisi (MAUT) kullanılarak değerlendirilmesidir. Araştırma verileri Our World in Data veri tabanlarmdan 15 Nisan 2021 tarihi itibariyle temin edilmiştir. Literatüre paralel olarak değerlendirmede kullanılmak üzere on dört ölçüt seçilmiştir. Kriterlerin objektif ağırlıklandırılmasında entropi yöntemi kullanılmış, nüfus yoğunluğu (15.6\%), yüz kişi bazında tüm dozlar aşılanmış insan sayısı (12.1\%), bin kişi bazında uygulanan test sayısı (10.2\%), diyabet yaygınlığı (8.9\%), pozitif oranı (8.5\%), kardiyovasküler ölüm oranı (8.3\%), milyon kişi bazında ölüm oranı $(7.3 \%)$, \%), yüz kişi bazında aşılanmış insan sayısı (6.1\%), milyon kişi bazında vaka sayısı (5.2\%), bin kişi başına düşen hastane yatağı sayısı (4.7\%), bin kişi başına düşen hemşire ve ebe sayısı (4.1\%), kapanma endeksi (3.4 $\%)$, bin kişi başına düşen doktor sayısı (3.1\%) ve 65 yaş üzeri nüfus oranı $(2.6 \%)$ stralaması elde edilmiştir. Ülkeler MAUT yöntemi ile siralandığında ilk beş ülkenin Bahreyn, Strbistan, Slovakya, Ísrail ve Slovenya olduğu, son beşülkenin ise Malezya, Norveç, Japonya, Finlandiya ve Güney Kore olduğu belirlenmiştir. Araştırma bulguları sonuç bölümünde tartışılmıştır.
\end{abstract}

Anahtar Kelimeler: $\quad$ COVID-19, Entropi, MAUT, Çok Kriterli Karar Verme. 


\section{Introduction}

Significant number of pneumonia cases with unknown causes has reported in a seafood market in Wuhan city, China in December 2019. After the first incidents, disease rapidly spread across China and to other countries. At the end of January 2020, World Health Organization (WHO) have announced that cause of the decease is related to 2019-nCoV/SARS-CoV2, COVID-19 virus in other words, and declared global pandemic. As the end of April 2021, it is reported that coronavirus have maintained its growing pattern of infectiousness in 192 countries/regions with over 880.000 new cases per day, effected more than 154 Million people all over the world, resulted 3.2 Million of them to lose their lives because of the reasons directly or indirectly attributed to Covid-19 (John Hopkins University Coronavirus Resource Center, 2021; World Health Organization, 2020c).

Although some governments are observed to take pandemic lightly as a first reaction, majority of them as well as organizations such as WHO, US Centers for Disease Control and Prevention (CDC), national surgical associations etc. have anticipated the devastating effects of COVID-19, attempted to increase awareness about it via various public disclosure channels, suggested and implemented preventive measures in order to apply barriers against the spreading. Common initial countermeasures were social distancing, mandatory use of face mask, travel restrictions, applying basic hygiene rules like hand washing or sanitizing, encouraging to avoid physical touch such as hand shaking and hugging in daily affairs, having proper nutrition, not sharing personal belongings that may transfer the virus etc. (Arsu, 2021; Singh and Avikal, 2020; World Health Organization, 2020a, 2020b).

After first months, especially with the development of clinical tests to identify the virus, governments have gone beyond the preliminary precautions and started to struggle with the pandemic by containment and closure policies (i.e. lockdown) such as school closures, restrictions in movement, limiting working hours of public and private offices, fostering work from home as well as increasing the number of tests, applying effective filiation (contact tracing) measures, increasing the number of facilities (ie. hospitals, pandemic centers etc.), increasing number of hospital beds 
(particularly intensive care departments), applying restrictions for travel, raising awareness in the population and most importantly expediting the efforts towards developing an effective vaccine (Dowd et al., 2020; World Health Organization, 2020c). Course of the pandemic has varied widely across the regions and countries in relation with several reasons. First, at the beginning of the process, there were little to no consensus on the countermeasures to be used to contain the situation among countries. Difference of opinions lead to apply a wide variety of precautions as well as different levels of strictness regarding to them, which are not fully compatible with each other, both domestically and internationally. Second, healthcare infrastructure (i.e. number of hospitals, beds, physicians, nurses, other healthcare professionals and qualifications of them) is an important determinant that significantly effect the strategy to be chosen to fight with the pandemic, which changes outcomes. Due to the inflexible nature of them, these elements are difficult to change in the short term hence countries had to fight with the disease with their current resources. Considering the initial phase, it can be stated that the speed of infectiousness have outperformed one of the most important factor to tackle with it, healthcare assets that countries have, especially in Spain, Italy, France and United Kingdom (John Hopkins University Coronavirus Resource Center, 2021; World Health Organization, 2020c). Third, population structure is another essential variable that has an effect on countries responses to pandemic. Specifically population density (number of people per square kilometers), age groups, share of the population that is 65 years and older as well as level chronical diseases such as diabetes, cardiovascular illnesses, cancer etc. are important since they are increasing the fatality of COVID19. Finally, although seems to be neglected as a research topic so far, cultural composition of countries can be a distinctive indicator on the progress of COVID-19 spread. Especially factors such as individualism-collectivism, power distance, uncertainty avoidance, long-short term orientation etc. may have effected individual behaviors during the pandemic, making things even harder for the governments in managing the crisis.

Literature shows that Multi Criteria Decision Making (MCDM) methods are widely applied for assessing various aspects of COVID-19 since they offer solutions to the complex problems that require using multiple and conflicting criteria in the process. For example, Breitenbach et al. 
(2020) used Data Envelopment Analysis (DEA) to analyze the 31 most infected countries during the first 100 days of outbreak, Ghasemi et al. (2020) calculated performances of 19 selected countries in two dimensions: inefficiency of preventing coronavirus spread and inefficiency of preventing deaths caused by a coronavirus using (DEA), Shirouyehzad et al. (2020) evaluated the performance of most seriously affected countries regarding contagion control and medical treatment of COVID-19 using (DEA), Sarwar and Imran (2021) used Analytical Hierarchical Process (AHP) method to evaluate and prioritize infection prevention and control activities for COVID-19, Marti and Puertas (2021) ranked countries using Technique for Order Preference by Similarity to the Ideal Solution (TOPSIS) method based on health, society and work criteria, Manupati et al. (2021) used Fuzzy VIKOR and TOPSIS methods for the selection of the best health care waste disposal technique, Albahri et al. (2020) provided a rescue framework for the transfusion of the best convalescent plasma to the most critical patients with COVID-19 on the basis of biological requirements by using opinion score method, Maqbool and Khan (2020) identified the barriers to implement public health and social measures for preventing transmission of COVID-19 using Decision Making Trial and Evaluation Laboratory (DEMATEL) method, Samanlıoğlu and Kaya (2020) assessed intervention strategy alternatives applied by various countries for the COVID-19 pandemic using hesitant fuzzy AHP method, Çalış Boyac1 (2021) ranked OECD countries in combating COVID-19 using TOPSIS, COPRAS, and ARAS methods according to the weights obtained by SWARA, Arsu (2021) assessed selected countries by using the health infrastructures, population characteristics and COVID-19 data with Entropy and WASPAS methods.

On the other hand, previous studies are observed to use common criteria which can considered as "generally accepted" for assessing and comparing countries regarding to COVID-19 such as number of COVID-19 cases per 100.000 people, number of recovered COVID-19 cases per 100.000 people, total deaths attributed to COVID-19 per 100.000 people, total tests for COVID-19 per 100.000 people, number of physicians per 100.000 people, number of nurses per 100.000 people, number of hospital beds per 100.000 people, health expenditures as \% of GDP, people aged 65 or older, population, population density per square kilometer, stringency 
index, number of days to lockdown, as well as personal elements like social distancing, hygiene, sharing personal belongings, unnecessary touching things, improper food habits, daily fresh food items, immunity/fitness etc. (Breitenbach et al., 2020; Ghasemi et al., 2020; Singh and Avikal, 2020; Shirouyehzad et al., 2020, Çalış Boyacı, 2021; Arsu, 2021).

The purpose of this research is to assess selected European and Asian countries COVID-19 statuses by using Entropy and MAUT Multi Criteria Decision Making methods. The study is organized as follows, after the introduction in which selected literature is briefly reviewed second section presents research methodology and findings, final section concludes and discusses findings.

\section{Methodology}

The research is conducted in three phases. In the first phase, countries and evaluation criteria are selected by taking previous studies and data availability into consideration. In the second phase, entropy method is used to calculate the weights of the criteria. Since entropy method presents an objective solution for the problem, possible effects of subjective evaluations regarding to the importance of variables are avoided to a certain extent. After weighting criteria, countries are ranked using Multi Attribute Utility Theory (MAUT) method in the third phase.

Data and Criteria: Data for this research is obtained from One Word in Data (OWID) databases as of April 15 $5^{\text {th }}, 2021$. OWID is a constitution that compiles data from various resources and make available for researchers which is focused on "research and data to make progress against the world's largest problems" that are stated as "poverty, disease, hunger, climate change, war, existential risks, and inequality" (https://ourworldindata.org/about). OWID material is trusted by institutions such as Royal Statistical Society, BBC, The New York Times, The Guardian, CNBC, The Washington Post, CNN, FT and used in the teaching of distinguished universities namely University of Oxford, Harvard University, Stanford University, University of Chicago, University of Cambridge, University of California Berkeley etc. Information provided under Coronavirus Pandemic (COVID-19) section of the OWID web site is used to 
determine the research countries and evaluation criteria by purely taking availability of data into consideration (https://ourworldindata.org/coronavirus). After thoroughly examining the data in the OWID databases following 27 Asia and Europe countries are selected (Table 1).

\section{Table 1. Research Countries}

\begin{tabular}{lll}
\hline Research Countries & & \\
\hline Bahrain & Italy & Russia \\
Bangladesh & Japan & Serbia \\
Belgium & Latvia & Slovakia \\
Bulgaria & Luxembourg & Slovenia \\
Estonia & Malaysia & South Korea \\
Finland & Norway & Spain \\
Greece & Poland & Switzerland \\
India & Portugal & Turkey \\
Israel & Romania & United Kingdom \\
\hline
\end{tabular}

Criteria descriptions and sources of the original data are shown in the Table 2.

Table 2. Assessment Criteria

\begin{tabular}{|c|c|c|}
\hline Criteria & Source & Description \\
\hline Total Cases per Million & $\begin{array}{l}\text { COVID-19 Data Repository by the Center } \\
\text { for Systems Science and Engineering } \\
\text { (CSSE) at Johns Hopkins University }\end{array}$ & $\begin{array}{l}\text { Thotal confirmed cases of COVID-19 per } \\
1,000,000 \text { people }\end{array}$ \\
\hline Total Deaths per Million & $\begin{array}{l}\text { COVID-19 Data Repository by the Center } \\
\text { for Systems Science and Engineering } \\
\text { (CSSE) at Johns Hopkins University }\end{array}$ & $\begin{array}{l}\text { Total deaths attributed to COVID-19 per } \\
1,000,000 \text { people }\end{array}$ \\
\hline Total Tests per Thousand & National government reports & $\begin{array}{l}\text { Total tests for COVID-19 per 1,000 peo- } \\
\text { ple }\end{array}$ \\
\hline Positive Rate & National government reports & $\begin{array}{l}\text { The share of COVID- } 19 \text { tests that are } \\
\text { positive, given as a rolling } 7 \text {-day average }\end{array}$ \\
\hline $\begin{array}{l}\text { People Vaccinated per } \\
\text { Hundred }\end{array}$ & National government reports & $\begin{array}{l}\text { Total number of people who received at } \\
\text { least one vaccine dose per } 100 \text { people in } \\
\text { the total population }\end{array}$ \\
\hline $\begin{array}{l}\text { People Fully Vaccinated } \\
\text { per Hundred }\end{array}$ & National government reports & $\begin{array}{l}\text { Total number of people who received all } \\
\text { doses prescribed by the vaccination pro- } \\
\text { tocol per } 100 \text { people in the total popula- } \\
\text { tion }\end{array}$ \\
\hline Stringency Index & $\begin{array}{l}\text { Oxford COVID-19 Government Re- } \\
\text { sponse Tracker, Blavatnik School of Gov- } \\
\text { ernment }\end{array}$ & $\begin{array}{l}\text { Government Response Stringency Index: } \\
\text { composite measure based on } 9 \text { response } \\
\text { indicators including school closures; } \\
\text { workplace closures; cancellation of pub- } \\
\text { lic events; restrictions on public gather- } \\
\text { ings; closures of public transport; stay-at- } \\
\text { home requirements; public information } \\
\text { campaigns; restrictions on internal }\end{array}$ \\
\hline
\end{tabular}


movements; and international travel controls rescaled to a value from 0 to 100 $(100=$ strictest response $)$.

\begin{tabular}{|c|c|}
\hline Population Density & $\begin{array}{l}\text { World Bank World Development Indica- Number of people divided by land area, } \\
\text { tors, sourced from Food and Agriculture measured in square kilometers, most re- } \\
\text { Organization and World Bank estimates cent year available }\end{array}$ \\
\hline Aged 65 Older & $\begin{array}{l}\text { World Bank World Development Indica- Share of the population that is } 65 \text { years } \\
\text { tors based on age/sex distributions of and older, most recent year available } \\
\text { United Nations World Population Pro- } \\
\text { spects } 2017 \text { Revision }\end{array}$ \\
\hline Cardiovascular Death Rat & $\begin{array}{ll}\text { eGlobal Burden of Disease Collaborative } & \text { Death rate from cardiovascular disease } \\
\text { Network, Global Burden of Disease } & \text { in } 2017 \text { (annual number of deaths per } \\
\text { Study } 2017 \text { Results } & 100,000 \text { people) } \\
\end{array}$ \\
\hline Diabetes Prevalence & $\begin{array}{l}\text { World Bank World Development Indica- Diabetes prevalence (\% of population } \\
\text { tors, sourced from International Diabetes aged } 20 \text { to } 79 \text { ) in } 2017 \\
\text { Federation, Diabetes Atlas }\end{array}$ \\
\hline $\begin{array}{l}\text { Medical Dr (per 1,000 Peo } \\
\text { ple) }\end{array}$ & $\begin{array}{l}\text { - World Health Organization's Global Physicians per } 1,000 \text { people, most recent } \\
\text { Health Workforce Statistics, OECD, sup- year available } \\
\text { plemented by country data. }\end{array}$ \\
\hline $\begin{array}{l}\text { Nurses and Midwives ( } p \\
1,000 \text { People) }\end{array}$ & $\begin{array}{l}\text { rWorld Health Organization's Global Nurses and midwives per 1,000 people, } \\
\text { Health Workforce Statistics, OECD, sup- most recent year available } \\
\text { plemented by country data. }\end{array}$ \\
\hline $\begin{array}{l}\text { Hospital Beds (per 1,000 } \\
\text { People) }\end{array}$ & $\begin{array}{l}\text { World Health Organization's Global Hospital beds per 1,000 people, most re- } \\
\text { Health Workforce Statistics, OECD, sup- cent year available } \\
\text { plemented by country data. }\end{array}$ \\
\hline
\end{tabular}

Entropy Method: Entropy term is originally introduced by Rudolph Clausisus in 1865 as a measure of unavailability of a system's energy to do work in thermodynamics. Entropy also refers to the uncertainty and disorder in a system; the higher the entropy value the greater the disorder (Zhang et al., 2011). Concept is adapted to information theory by Shannon (1948) representing a measure of the uncertainty associated with a random variable. Information entropy suggests that the number or quality of information acquired from decision-making setting is one of the determinants of accuracy and reliability of decision-making problem (Wu et al., 2011). Entropy is asserted to be a good method that can be used to measure the quantity of useful information provided by data itself, hence it is widely used especially in physics, mathematics, engineering as well as social sciences in recent years (Erdoğan et al., 2020). Entropy method provides objective weighting of the variables and contains four calculation steps:

Preparation of Evaluation Matrix: Considering there are $m$ alternatives and $n$ evaluation criteria, decision matrix is formed as follows: 


$$
X=\left[\begin{array}{cccc}
\mathrm{X}_{11} & \mathrm{x}_{12} & \ldots & \mathrm{x}_{1 \mathrm{n}} \\
\mathrm{X}_{21} & \mathrm{x}_{22} & \ldots & \mathrm{x}_{2 \mathrm{n}} \\
\vdots & \vdots & & \vdots \\
\mathrm{X}_{\mathrm{m} 1} & \mathrm{x}_{\mathrm{m} 2} & \ldots & \mathrm{x}_{\mathrm{mn}}
\end{array}\right]=\left(\begin{array}{llll}
\mathrm{X}_{1} & \mathrm{X}_{2} & \ldots & \mathrm{X}_{\mathrm{n}}
\end{array}\right)
$$

Normalization of the evaluation matrix: Since the values of the indicators show differences in terms of units or intervals, for the purpose of eliminating the effect of different units on the evaluation results (to avoid incommensurability) each indicator needs to be standardized in a way that the total of all alternative values are equal to 1 (Li et al., 2011).

$r_{i j}$ normalized values are calculated by using cost and benefit indicators with Formula (2) assuming there are $m$ alternatives $(i=1,2,3, \ldots m)$ and $n$ criteria $(j=1,2,3, \ldots n) \cdot x_{i j}(i=1,2, \ldots, m ; j=1,2, \ldots, n)$ represents the value of the $i^{\text {th }}$ evaluation alternative in the $j^{\text {th }}$ indicator ( $\mathrm{Wu}$ et al., 2011; Chen, 2020).

$$
r_{i j}=\left\{\begin{array}{cl}
\frac{x_{i j}-\min _{i}\left(x_{i j}\right)}{\max _{i}\left(x_{i j}\right)-\min _{i}\left(x_{i j}\right)}, & \text { benefit indicator } \\
\frac{\max _{i}\left(x_{i j}\right)-x_{i j}}{\max _{i}\left(x_{i j}\right)-\min _{i}\left(x_{i j}\right)}, & \text { cost indicator }
\end{array}\right.
$$

Determination of the entropy values: Entropy value of the $j^{\text {th }}$ criterion $\left(e_{j}\right)$ is determined using Formula (3) where entropy constant is $k=1 / \mathrm{ln} m$.

$$
e_{j}=-k \sum_{i=1}^{m} r_{i j} \ln \left(r_{i j}\right)
$$

Determination of entropy based weights: Entropy weight represents useful information of the evaluation index. Therefore, the bigger the entropy weight of the indicator is, the more useful it is in terms of providing information (Li et al., 2011). Entropy weights are calculated by using Formula (4)

$$
w_{j}=\frac{1-e_{j}}{\sum_{j=1}^{n}\left(1-e_{j}\right)}
$$


MAUT Method: MAUT method is first presented in Fisburn's (1967) and Fisburn and Keeney's (1974) studies before putting in the final form by Loken in 2007. Since MAUT incorporates risk preferences and uncertainty into multi criteria decision making and provide a tractable process to make tradeoffs among conflicting objectives it is widely used in decision making problems (Keeney and Raiffa, 1976; Loken, 2007; Konuşkan and Uygun, 2014). Underlying assumption of the method is that there is a real valued function or utility $(U)$ defined by the set of feasible alternatives that the decision-maker seeks to maximize (Olson, 1996).

The MAUT approach can be summarized into the following steps (Zietsman et al., 2006; Konuşkan and Uygun, 2014):

1. Determination of the criteria and alternatives to be used in the decision matrix: Criteria and alternatives to be used in the problem is determined and the decision matrix is prepared in this step.

2. Normalization of the decision matrix: $r_{i j}$ normalized values where $l_{j}^{-}=\min _{i}\left(x_{i j}\right)$ and $\left(x_{i j}\right)$ are calculated by using utility and cost criteria with Formula (5).

$$
r_{i j}= \begin{cases}\frac{x_{i j}-l_{j}^{-}}{u_{j}^{+}-l_{j}^{-}}, & \text {utility criteria } \\ \frac{u_{j}^{+}-x_{i j}}{u_{j}^{+}-l_{j}^{-}}, & \text {cost criteria }\end{cases}
$$

3. Calculation of the utility values for alternatives: Utility values for each alternative $\left(U_{i}\right)$ are calculated by using Formula (6) where $w_{i}$ is weight of the $i^{\text {th }}$ criterion, $r_{i j}$ is normalized criterion $i$ value for alternative $j$.

$$
U_{i}=\sum_{j=1}^{n} w_{i} r_{i j}
$$

4. Ranking alternatives : Utility values $\left(U_{i}\right)$ obtained are sorted in descending order to rank alternatives. The bigger utility values indicate better alternatives. 


\section{Analyses and Findings}

Evaluation matrix, which is composed of the data obtained from OWID databases, is presented in Table 3 . Total cases per million, total deaths per million, positive rate, population density, aged 65 older, cardiovascular death rate, diabetes prevalence are negative criteria where smaller values are better and total tests per thousand, people vaccinated per hundred, people fully vaccinated per hundred, stringency index, Medical Dr per thousand, Nurses and midwives per thousand, hospital beds per thousand are positive criteria where bigger values are better.

Looking closer, it can be asserted that no country has an absolute advantage or disadvantage when all criteria are taken into account. Depending on the geographical, demographic and infrastructural conditions countries have their own vulnerabilities and strengths related to COVID19 pandemic.

Table 3. Evaluation Matrix

\begin{tabular}{|c|c|c|c|c|c|c|c|c|c|c|c|c|c|c|}
\hline $\begin{array}{l}\text { Alter- } \\
\text { nati- } \\
\text { ves/C } \\
\text { rite- } \\
\text { ria }\end{array}$ & $\begin{array}{c}\text { Total } \\
\text { Cases } \\
\text { per } \\
\text { Mil- } \\
\text { lion }\end{array}$ & $\begin{array}{l}\text { Total } \\
\text { De- } \\
\text { aths } \\
\text { per } \\
\text { Mil- } \\
\text { lion }\end{array}$ & $\begin{array}{c}\text { Total } \\
\text { Tests } \\
\text { per } \\
\text { Tho- } \\
\text { u- } \\
\text { sand }\end{array}$ & $\begin{array}{c}\text { Po- } \\
\text { si- } \\
\text { tiv } \\
\text { e } \\
\text { Rat } \\
\text { e }\end{array}$ & $\begin{array}{c}\text { Pe- } \\
\text { ople } \\
\text { Vac- } \\
\text { ci- } \\
\text { na- } \\
\text { ted } \\
\text { per } \\
\text { Hun } \\
\text { dred }\end{array}$ & $\begin{array}{c}\text { Pe- } \\
\text { ople } \\
\text { Full } \\
\text { y } \\
\text { Vac- } \\
\text { ci- } \\
\text { na- } \\
\text { ted } \\
\text { per } \\
\text { Hun } \\
\text { dred }\end{array}$ & $\begin{array}{c}\text { Stri } \\
\text { nge } \\
\text { ncy } \\
\text { In- } \\
\text { dex }\end{array}$ & $\begin{array}{c}\text { Po- } \\
\text { pula- } \\
\text { tion } \\
\text { Den- } \\
\text { sity }\end{array}$ & $\begin{array}{l}\text { Ag } \\
\text { ed } \\
65 \\
\text { O1- } \\
\text { der }\end{array}$ & $\begin{array}{c}\text { Car- } \\
\text { dio- } \\
\text { vas- } \\
\text { cu- } \\
\text { lar } \\
\text { De- } \\
\text { ath } \\
\text { Rat } \\
\text { e }\end{array}$ & $\begin{array}{c}\text { Di- } \\
\text { a- } \\
\text { be- } \\
\text { tes } \\
\text { Pre } \\
\text { va- } \\
\text { len } \\
\text { ce }\end{array}$ & $\begin{array}{c}\text { Me } \\
\text { di- } \\
\text { cal } \\
\text { Dr } \\
\text { per } \\
\text { Th } \\
\text { ou- } \\
\text { san } \\
\text { d }\end{array}$ & $\begin{array}{c}\text { Nurses } \\
\text { and } \\
\text { Midwi } \\
\text { ves } \\
\text { per } \\
\text { Thou- } \\
\text { sand }\end{array}$ & $\begin{array}{c}\text { Ho } \\
\text { spi } \\
\text { tal } \\
\text { Be } \\
\text { ds } \\
\text { per } \\
\text { Th } \\
\text { ou- } \\
\text { san } \\
\text { d }\end{array}$ \\
\hline $\begin{array}{l}\text { Bah- } \\
\text { rain } \\
\text { Bang- }\end{array}$ & $\begin{array}{c}94.578 \\
99\end{array}$ & $\begin{array}{c}337,3 \\
3\end{array}$ & $\begin{array}{c}2.253 \\
54\end{array}$ & $\begin{array}{l}0,0 \\
61\end{array}$ & $\begin{array}{c}34,2 \\
3\end{array}$ & $\begin{array}{c}26,2 \\
0\end{array}$ & $\begin{array}{c}56,4 \\
8\end{array}$ & $\begin{array}{c}1.935 \\
91\end{array}$ & 2,37 & $\begin{array}{c}151, \\
69\end{array}$ & $\begin{array}{l}16, \\
52\end{array}$ & $\begin{array}{c}0,9 \\
2\end{array}$ & 2,49 & $\begin{array}{c}2,0 \\
0\end{array}$ \\
\hline $\begin{array}{l}\text { la- } \\
\text { desh }\end{array}$ & $\begin{array}{c}4.295,1 \\
3\end{array}$ & 61,21 & 31,06 & $\begin{array}{l}0,2 \\
06\end{array}$ & 3,45 & 0,56 & $\begin{array}{c}83,3 \\
3\end{array}$ & $\begin{array}{c}1.265 \\
04\end{array}$ & 5,10 & $\begin{array}{c}298 \\
00\end{array}$ & $\begin{array}{c}8,3 \\
8\end{array}$ & $\begin{array}{c}0,4 \\
7\end{array}$ & 0,27 & $\begin{array}{c}0,8 \\
0\end{array}$ \\
\hline $\begin{array}{l}\text { Bel- } \\
\text { gium }\end{array}$ & $\begin{array}{c}81.047 \\
47\end{array}$ & $\begin{array}{c}2.039 \\
41\end{array}$ & $\begin{array}{c}1.027 \\
32\end{array}$ & $\begin{array}{l}0,0 \\
99\end{array}$ & $\begin{array}{c}19,0 \\
7\end{array}$ & 6,15 & $\begin{array}{c}75,9 \\
3\end{array}$ & $\begin{array}{c}375,5 \\
6\end{array}$ & $\begin{array}{c}18,5 \\
7\end{array}$ & $\begin{array}{c}114 \\
90\end{array}$ & $\begin{array}{c}4,2 \\
9\end{array}$ & $\begin{array}{c}3,0 \\
1\end{array}$ & 11,09 & $\begin{array}{c}5,6 \\
4\end{array}$ \\
\hline $\begin{array}{l}\text { Bul- } \\
\text { garia }\end{array}$ & $\begin{array}{c}55.085 \\
85\end{array}$ & $\begin{array}{c}2.155 \\
73\end{array}$ & $\begin{array}{c}333,7 \\
8\end{array}$ & $\begin{array}{c}0,1 \\
62\end{array}$ & 7,15 & 1,78 & $\begin{array}{c}53,7 \\
0\end{array}$ & 65,18 & $\begin{array}{c}20,8 \\
0\end{array}$ & $\begin{array}{c}424 \\
69\end{array}$ & $\begin{array}{c}5,8 \\
1\end{array}$ & $\begin{array}{c}4,0 \\
0\end{array}$ & 5,32 & $\begin{array}{c}7,4 \\
5\end{array}$ \\
\hline $\begin{array}{l}\text { Esto- } \\
\text { nia }\end{array}$ & $\begin{array}{c}87.596 \\
37\end{array}$ & $\begin{array}{c}802,0 \\
9\end{array}$ & $\begin{array}{c}919,2 \\
7\end{array}$ & $\begin{array}{l}0,1 \\
16\end{array}$ & $\begin{array}{c}20,9 \\
3\end{array}$ & 6,10 & $\begin{array}{c}61,1 \\
1\end{array}$ & 31,03 & $\begin{array}{c}19,4 \\
5\end{array}$ & $\begin{array}{c}255 \\
57\end{array}$ & $\begin{array}{c}4,0 \\
2\end{array}$ & $\begin{array}{c}3,4 \\
3\end{array}$ & 6,37 & $\begin{array}{c}4,6 \\
9\end{array}$ \\
\hline
\end{tabular}




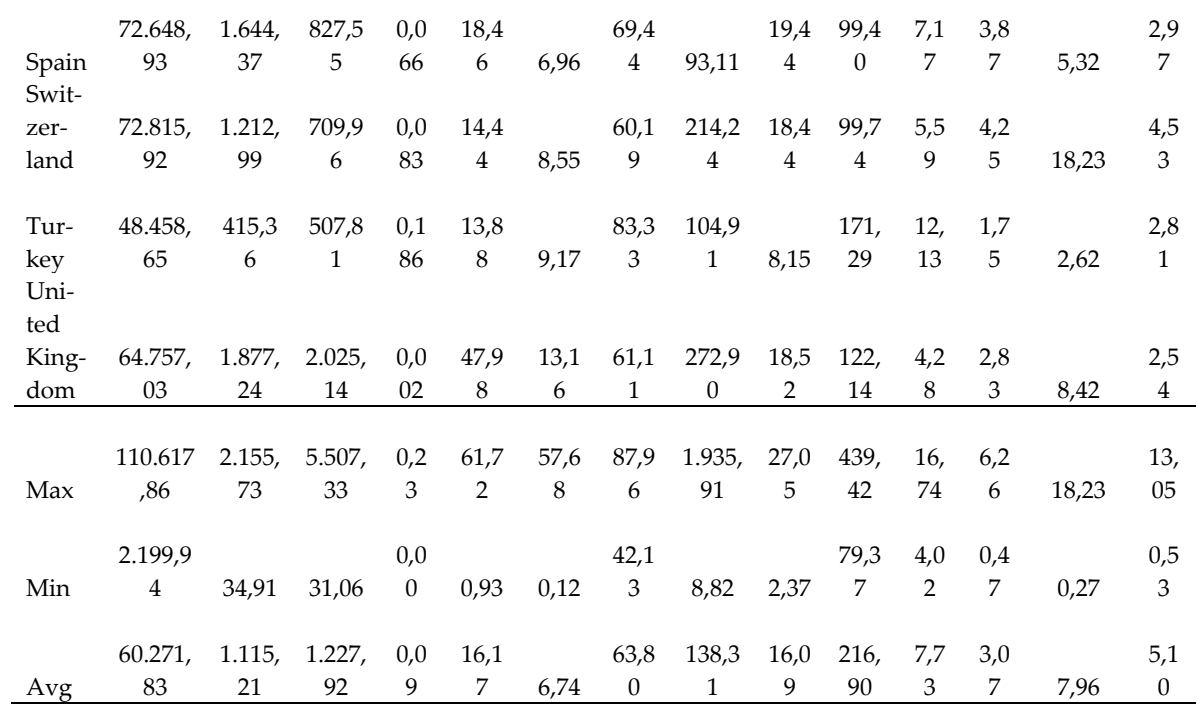

Taking top and bottom $20 \%$ values for each criterion into account it can be commented that:

- Bahrain, Israel, Luxembourg, Serbia and Slovenia has the highest, Bangladesh, India, Japan, Malaysia and South Korea has the lowest cases per million,

- Belgium, Bulgaria, Italy, Slovakia and Slovenia has the highest, Bangladesh, India, Japan, Malaysia and South Korea has the lowest deaths per million,

- Bahrain, Israel, Luxembourg, Slovakia and United Kingdom has the highest, Bangladesh, India, Japan, Malaysia and South Korea has the lowest total tests per thousand,

- Bangladesh, Poland, Serbia, Slovenia and Turkey has the highest, Israel, Portugal, Slovakia, South Korea and United Kingdom has the lowest positive rates,

- Bahrain, Finland, Israel, Serbia and United Kingdom has the highest, Bangladesh, Japan, Malaysia, Russia and South Korea has the lowest vaccination per hundred,

- Bahrain, Israel, Serbia, Turkey and United Kingdom has the highest, Bangladesh, India, Japan, Malaysia and South Korea has the lowest people fully vaccinated per hundred, 
- Bangladesh, Greece, Italy, Poland and Turkey has the highest, Finland, Israel, Japan, Malaysia and Russia has the lowest stringency index values,

- Bahrain, Bangladesh, India, Israel and South Korea has the highest, Estonia, Finland, Latvia, Norway and Russia has the lowest population density,

- Bulgaria, Finland, Italy, Japan and Portugal has the highest, Bahrain, Bangladesh, India, Malaysia and Turkey has the lowest share of the population that is 65 years and older,

- Bulgaria, Latvia, Romania, Russia and Serbia has the highest, Israel, Japan, South Korea, Spain and Switzerland has the lowest cardiovascular death rate,

- Bahrain, India, Malaysia, Serbia and Turkey has the highest, Belgium, Estonia, Greece, Luxembourg and United Kingdom has the lowest diabetes prevalence,

- Greece, Italy, Norway, Portugal and Switzerland has the highest, Bahrain, Bangladesh, India, Malaysia and Turkey has the lowest number of physicians per 1,000 people,

- Finland, Japan, Luxembourg, Norway and Switzerland has the highest, Bahrain, Bangladesh, Greece, India and Turkey has the lowest number of nurses and midwives per 1,000 people,

- Bulgaria, Japan, Romania, Russia and South Korea has the highest, Bahrain, Bangladesh, India, Malaysia and United Kingdom has the lowest number of Hospital beds per 1,000 people.

After preparation of the decision matrix, in order to eliminate the effect of differences in the units, indicators are normalized by using formula (2) taking cost and benefit structure of them into account. After the normalization, indicator weights are calculated with formulas (3) and (4). Table 4 shows entropy and $w_{j}$ values that represent the relative importance coefficient of each indicator, entropy weights in other words. 
Table 4. Entropy Values and Weights of Indicators

\begin{tabular}{lccc}
\hline & ej & 1-ej & wj \\
\hline Population Density & 0,773 & 0,227 & 0,156 \\
People Fully Vaccinated per Hundred & 0,825 & 0,175 & 0,121 \\
Total Tests per Thousand & 0,851 & 0,149 & 0,102 \\
Diabetes Prevalence & 0,871 & 0,129 & 0,089 \\
Positive Rate & 0,877 & 0,123 & 0,085 \\
Cardiovascular Death Rate & 0,880 & 0,120 & 0,083 \\
Total Deaths per Million & 0,895 & 0,105 & 0,073 \\
People Vaccinated per Hundred & 0,911 & 0,089 & 0,061 \\
Total Cases per Million & 0,925 & 0,075 & 0,052 \\
Hospital Beds per Thousand & 0,932 & 0,068 & 0,047 \\
Nurses and Midwives per Thousand & 0,940 & 0,060 & 0,041 \\
Stringency Index & 0,950 & 0,050 & 0,034 \\
Medical Dr per Thousand & 0,955 & 0,045 & 0,031 \\
Aged 65 older & 0,963 & 0,037 & 0,026 \\
\hline
\end{tabular}

Results indicate that criteria with highest weights are population density $(15.6 \%)$, people fully vaccinated per hundred $(12.1 \%)$, total tests per thousand $(10.2 \%)$, diabetes prevalence $(8.9 \%)$, positive rate $(8.5 \%)$, cardiovascular death rate $(8.3 \%)$, total deaths per million $(7.3 \%)$ representing $70.8 \%$ in total. On the other hand, lowest weights are obtained for hospital beds per thousand $(4.7 \%)$, nurses and midwives per thousand $(4.1 \%)$, stringency index (3.4\%), medical Dr per thousand (3.1\%) and share of the population that is 65 years and older $(2.6 \%)$. It should be noted that although these indicators are useful for ranking countries in a broad sense, it may not be the case as far as the struggle with the pandemic is concerned because governments have only a certain degree of control over in most of them (i.e. population density, vaccination, diabetes and cardiovascular deceases, healthcare infrastructure etc.). However, in order to achieve to the goal of the study parameters given above are used to assess country statutes assuming that strategies for managing the pandemic needs to be developed taking all into consideration whether or not they are controllable or changeable by the governments in the short term.

After weighting indicators with entropy method, utility values for each country are calculated with MAUT method using formulas (5) and (6). Results are shown in Table 5. 
Table 5. Utility Values for Each Alternative

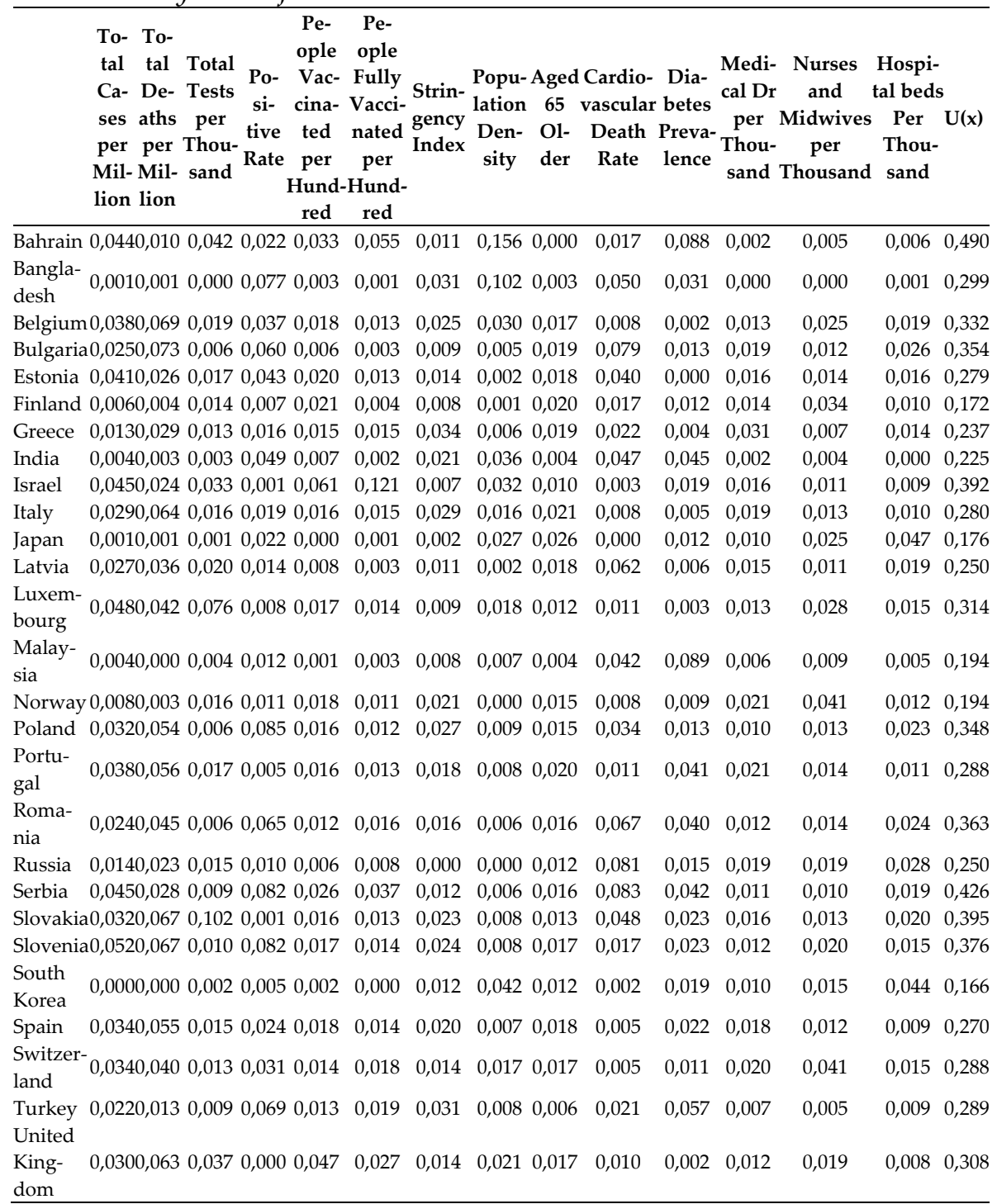

Finally, alternatives are sorted based on total utility values calculated. Table 6 presents country ranking in descending order. 
Table 6. Ranking of Alternatives

\begin{tabular}{llllll}
\hline $\mathbf{1}$ & Bahrain & 0,490 & $\mathbf{1 4}$ & Portugal & 0,288 \\
$\mathbf{2}$ & Serbia & 0,426 & $\mathbf{1 5}$ & Switzerland & 0,288 \\
$\mathbf{3}$ & Slovakia & 0,395 & $\mathbf{1 6}$ & Italy & 0,280 \\
$\mathbf{4}$ & Israel & 0,392 & $\mathbf{1 7}$ & Estonia & 0,279 \\
$\mathbf{5}$ & Slovenia & 0,376 & $\mathbf{1 8}$ & Spain & 0,270 \\
$\mathbf{6}$ & Romania & 0,363 & $\mathbf{1 9}$ & Russia & 0,250 \\
$\mathbf{7}$ & Bulgaria & 0,354 & $\mathbf{2 0}$ & Latvia & 0,250 \\
$\mathbf{8}$ & Poland & 0,348 & $\mathbf{2 1}$ & Greece & 0,237 \\
$\mathbf{9}$ & Belgium & 0,332 & $\mathbf{2 2}$ & India & 0,225 \\
$\mathbf{1 0}$ & Luxembourg & 0,314 & $\mathbf{2 3}$ & Malaysia & 0,194 \\
$\mathbf{1 1}$ & United Kingdom & 0,308 & $\mathbf{2 4}$ & Norway & 0,194 \\
$\mathbf{1 2}$ & Bangladesh & 0,299 & $\mathbf{2 5}$ & Japan & 0,176 \\
$\mathbf{1 3}$ & Turkey & 0,289 & $\mathbf{2 6}$ & Finland \\
& & & $\mathbf{2 7}$ & South Korea \\
\hline
\end{tabular}

\section{Conclusion}

COVID-19 pandemic is claimed to be one of the most significant health crisis humanity faced and probably the most devastating one that occurred in the life-cycle of the current population. It has negative effects on not only to individual well-being but also to health systems, economies, mass psychology, social, political and cultural life as well. According to the WHO COVID-19 Dashboard there are 164.523.894 confirmed cases, 3.412.032 deaths, 1.407.945.776 vaccine doses administered and 638.247 new cases per day as of May 21th, 2021 (https:/covid19.who.int/). Although a downtrend is seen especially in the speed of the spread and mortality rates compared to previous month, it can be asserted that COVID19 will remain to be an important problem that needs to be closely monitored for majority of the countries worldwide in the short term.

In this research selected European and Asian countries COVID-19 statuses are evaluated by using multi criteria decision making methods. Entropy method is used for objectively weighting the criteria and MAUT method is used for ranking countries based on their utility values. MAUT is one of few MCDM methods designed especially for handling risk and uncertainties taking into consideration all the criteria at hand even though they are conflicting.

Results show following weighting for the criteria:

- Population Density: $15.6 \%$,

- People Fully Vaccinated per Hundred: $12.1 \%$,

- Total Tests per Thousand: $10.2 \%$,

- Diabetes Prevalence: $8.9 \%$, 
- Positive Rate: $8.5 \%$,

- Cardiovascular Death Rate: $8.3 \%$,

- Total Deaths per Million: 7.3\%,

- People Vaccinated per Hundred: $6.1 \%$,

- Total Cases per Million: 5.2\%,

- Hospital Beds per Thousand: $4.7 \%$,

- Nurses and Midwives per Thousand: $4.1 \%$,

- Stringency Index: $3.4 \%$,

- Medical Dr per Thousand: 3.1\%,

- Share of the Population that is 65 Years and Older: $2.6 \%$.

Considering criteria weights it can be asserted that results are in line with the previous studies especially when generally accepted health indicators such as total tests, positive rate, total deaths, number of people fully vaccinated, chronical deceases that strengthens the negative effects of COVID-19 are concerned. Three particularly interesting results that needs to be emphasized which require further analysis are relative importance of population density, low weights obtained both for stringency index and criteria that represent healthcare infrastructure (medical Dr per thousand, nurses and midwives per thousand, hospital beds per thousand).

Population density shows the number of people per square kilometers and calculated as the criteria which have the biggest weight using the research dataset. Logically, possibility of infection as well as speed of spread is relatable to the larger population and the smaller habitable environment that a country has. This assumption can be used not only at the macro level (i.e. land in square kilometers and population) but at micro level as well considering the proportions of residential areas, business areas, recreational areas that cities have. The main reason behind restricting public gatherings, internal movements and applying stay-at-home requirements is to prevent people to group in small areas such as city centers, town squares, public parks, business centers, shopping malls etc. that can provide a convenient environment for COVID-19 infectiousness by increasing population density. Although it is found to be the most important criterion in the evaluation process population density seems to be neglected as far as the current COVID-19 and MCDM literature is concerned.

Low weight obtained for stringency index is an unexpected result. Since index is consisted of precautions such as school closures, workplace 
closures, cancellation of public events, restrictions on public gatherings, closures of public transport, stay-at-home requirements, public information campaigns, restrictions on internal movements and international travel controls, it is expected to have a greater weight. However, when Table 3 is closely examined countries which has higher stringency index such as Bangladesh, Slovenia, Slovakia and Belgium are also observed to have higher number of total cases, total deaths per million and/or high positive rates and/or low number of people fully vaccinated per hundred etc. On the other hand, these countries are ranked relatively better compared to other countries as well (Table 6). Taking all into account, it can be argued that there is a causal relationship between these criteria and stringency implying that in order to achieve best results precautions needs to be applied in combination with others.

Contrary to the previous findings criteria that represent healthcare infrastructure is found to be relatively less weighted in this study. Results showed only $11.9 \%$ of the total criteria weigh is consisted of medical Drs per thousand, nurses and midwives per thousand and hospital beds per thousand that practically indicate countries most important resources to fight with the pandemic. Number of the physicians, nurses, other healthcare professionals and hospital capacities are crucial for the patients whose overall health status requires hospitalization -especially for the ones who need intensive care-. On the other hand the need for them increases disproportionally with the growth of total number of the patients since neither the number of healthcare professionals nor infrastructure cannot be developed in the short term. Due to this reason results can be taken as they are laying emphasis on the importance of preventive healthcare. Applying preventive measures such as intensive vaccination and testing, filiation, social distancing, managing high risk groups as much as possible can be a more efficient approach than striving hard to cure it after getting infected.

MAUT analyses results indicate that first five countries are found to be Bahrain, Serbia, Slovakia, Israel and Slovenia and last five countries are Malaysia, Norway, Japan, Finland and South Korea. Reviewing Table 3, findings confirm the importance of population density, people fully vaccinated per hundred, total tests per thousand and positive rate criteria that 
produced the results. In conclusion, it can be suggested for healthcare administrations to use these criteria among others on monitoring as well as decision making processes. Findings of this study can provide insights to COVID-19 literature. This research is a cross sectional study in which data obtained from OWID is used. Future studies are suggested to examine COVID-19 phenomenon by taking more countries into consideration, using additional indicators and more advanced analysis methods, different data sources, conducting longitudinal studies to establish a basis for comparison.

\section{References}

Albahri, O. S., Al-Obaidi, J. R., Zaidan, A. A., Albahri, A. S., Zaidan, B. B., Salih, M. M. and Zulkifli, C. Z. (2020). Helping doctors hasten COVID19 treatment: Towards a rescue framework for the transfusion of best convalescent plasma to the most critical patients based on biological requirements via $\mathrm{ml}$ and novel MCDM methods. Computer methods and programs in biomedicine, 196, 105617.

Arsu, T . (2021). Ülkelerin Covid-19 Pandemisine karşı mücadelesinin çok kriterli karar verme yöntemleri ile değerlendirilmesi . Bitlis Eren Üniversitesi İktisadi Ve İdari Bilimler Fakültesi Akademik İzdüşüm Dergisi, 6(1), 128-140.

Breitenbach, M. C., Ngobeni, V. and Aye, G. C. (2021). Efficiency Of Healthcare Systems In The First Wave Of Covid-19-A Technical Efficiency Analysis. Economic Studies, 30(6).

Chen, C. H. (2020). A novel multi-criteria decision-making model for building material supplier selection based on entropy-AHP weighted TOPSIS. Entropy, 22(2), 259.

Çalış Boyacı, A . (2021). Which OECD countries are advantageous in fight against COVID-19? Erciyes Üniversitesi Fen Bilimleri Enstitüsü Fen Bilimleri Dergisi, 37(1) , 137-148 .

Dowd, J. B., Andriano, L., Brazel, D. M., Rotondi, V., Block, P., Ding, X. and Mills, M. C. (2020). Demographic science aids in understanding the spread and fatality rates of COVID-19. Proceedings of the National Academy of Sciences, 117(18), 9696-9698. 
Erdoğan, N. K., Altinirmak, S., Şahin, C. and Karamaşa, Ç. (2020). Analyzing the financial performance of football clubs listed in BIST using entropy based copras methodology. Dumlupinar Üniversitesi Sosyal Bilimler Dergisi, 63, 39-53.

Fishburn, P. C. (1967). Additive utilities with finite sets: Applications in the management sciences. Naval Research Logistics Quarterly, 14(1), 1-13.

Fishburn, P. C. and Keeney, R. L. (1974). Seven independence concepts and continuous multiattribute utility functions. Journal of Mathematical Psychology, 11(3), 294-327.

Ghasemi, A., Boroumand, Y. and Shirazi, M. (2020), How Do Governments Perform in Facing COVID- 19? , MPRA Pap.

John Hopkins University Coronavirus Resource Center, 2021. https://coronavirus.jhu.edu/, Retrieved 2021, April 25.

Keeney, R.L. and Raiffa, H, (1976). Decisions with multiple objectives. New York: Wiley.

Konuşkan, Ö. and Uygun, Ö. (2014). Çok nitelikli karar verme (MAUT) yöntemi ve bir uygulaması. ISITES, 2014, 1403-1412.

Li, X., Wang, K., Liu, L., Xin, J., Yang, H. and Gao, C. (2011). Application of the entropy weight and TOPSIS method in safety evaluation of coal mines. Procedia Engineering, 26, 2085-2091.

Løken, E. (2007). Use of multicriteria decision analysis methods for energy planning problems. Renewable and sustainable energy reviews, 11(7), 1584-1595.

Maqbool, A. and Khan, N. Z. (2020). Analyzing barriers for implementation of public health and social measures to prevent the transmission of COVID-19 disease using DEMATEL method. Diabetes $\mathcal{E}$ Metabolic Syndrome: Clinical Research E Reviews, 14(5), 887-892.

Manupati, V. K., Ramkumar, M., Baba, V. and Agarwal, A. (2021). Selection of the best healthcare waste disposal techniques during and post COVID-19 pandemic era. Journal of Cleaner Production, 281, 125175.

Marti, L. and Puertas, R. (2021). European countries' vulnerability to COVID19: Multicriteria decision-making techniques. Economic ResearchEkonomska Istraživanja, 1-12.

Olson, D.L. (1996) Decision aids for selection problems. New York: Springer.

Samanlioglu, F. and Kaya, B. E. (2020). Evaluation of the COVID-19 pandemic intervention strategies with hesitant F-AHP. Journal of Healthcare Engineering, 2020. 
Sarwar, A. and Imran, M. (2021). Prioritizing infection prevention and control activities for SARS-CoV-2 (COVID-19): A multi-criteria decision-analysis method. Journal of Healthcare Leadership, 13, 77.

Shannon, C. E. (1948). A mathematical theory of communication. Bell System Technical Journal, 27, 379-423.

Shirouyehzad, H., Jouzdani, J. and Khodadadi Karimvand, M. (2020). Fight against COVID-19: A global efficiency evaluation based on contagion control and medical treatment. Journal of Applied Research on Industrial Engineering, 7(2), 109-120.

Singh, R. and Avikal, S. (2020). COVID-19: A decision-making approach for prioritization of preventive activities. International Journal of Healthcare Management, 13(3), 257-262.

World Health Organization (2020a). Coronavirus disease 2019 (COVID-19): situationreport,72.WorldHealthOrganization.

https://apps.who.int/iris/handle/10665/331685

World Health Organization (2020b). Coronavirus disease 2019 (COVID-19): situation report, 43. World Health Organization. https://apps.who.int/iris/handle/10665/331354

World Health Organization (2020c). Novel Coronavirus (2019-nCoV): situation report, 11 . World Health Organization. https://apps.who.int/iris/handle/10665/330776

Wu, J., Sun, J., Liang, L. and Zha, Y. (2011). Determination of weights for ultimate cross efficiency using Shannon entropy. Expert Systems with Applications, 38(5), 5162-5165.

Zhang, H., Gu, C. L., Gu, L. W. and Zhang, Y. (2011). The evaluation of tourism destination competitiveness by TOPSIS \& information entropyA case in the Yangtze River Delta of China. Tourism Management, 32(2), 443-451.

Zietsman, J., Rilett, L. R. and Kim, S. J. (2006). Transportation corridor decision-making with multi-attribute utility theory. International Journal of Management and decision making, 7(2-3), 254-266.

\section{Kaynakça Bilgisi / Citation Information}

Bolelli, M. (2021). Assessment of selected European and Asian Countries COVID-19 statuses using entropy and MAUT Methods. OPUS-International Journal of Society Studies, 18(44), 7483-7504. DOI: 10.26466/opus. 943167. 